(c) American Dairy Science Association, 2003.

\title{
Differential Leukocyte Count Method for Bovine Low Somatic Cell Count Milk
}

\author{
H. Dosogne, F. Vangroenweghe, J. Mehrzad, A. M. Massart-Leën, and C. Burvenich \\ Ghent University, Faculty of Veterinary Medicine \\ Department of Physiology, Biochemistry and Biometrics \\ Salisburylaan 133, 9820 Merelbeke, Belgium
}

\section{ABSTRACT}

Whereas many differential leukocyte count methods for high somatic cell count (SCC) milk from mastitic cows are available, only a few have been developed for low SCC milk. We have developed a flow cytometric differential leukocyte count method for low SCC milk. The procedure consists of 1) $1.5 \mathrm{ml}$ of diluted milk sample (30\%, vol/vol dilution with PBS), 2) centrifugation, 3) leukocyte labeling with SYTO 13 and 4) flow cytometric analysis. Four major leukocyte populations can be clearly identified in the green fluorescence-side scatter dot plot: lymphocytes and monocytes (LM), polymorphonuclear neutrophils (PMN), mature macrophages $(\mathrm{M} \Phi)$, and cells with apoptotic features based on chromatin condensation and nuclear fragmentation. The optimal processing temperature was $20^{\circ} \mathrm{C}$. Significant differences among samples with similar differential leukocyte counts were found. Storage of milk samples during $2 \mathrm{~d}$ at $7^{\circ} \mathrm{C}$ had no effect on differential leukocyte count. Using the new method, differential leukocyte count was performed in low SCC milk samples from cows in early, mid, and late lactation. In accordance with previous studies, PMN and $\mathrm{M} \Phi$ percentages were lower and LM percentages were higher in early lactation than in the other stages of lactation. The percentage of cells with apoptotic features was higher in early lactation than in mid and late lactation. In conclusion, a rapid, simple, accurate, and reproducible standard procedure was developed to determine the differential leukocyte count ( $\mathrm{M} \Phi, \mathrm{PMN}, \mathrm{LM}$, and cells with apoptotic features) of bovine low SCC milk.

(Key words: differential leukocyte count, flow cytometry, low somatic cell count milk)

Abbreviation key: $\mathbf{F S}=$ forward scatter, $\mathbf{L M}=$ lymphocytes and monocytes, $\mathbf{M} \Phi=$ macrophage, $\mathbf{P M N}=$ polymorphonuclear neutrophil, $\mathbf{S S C}=$ side scatter.

Received January 22, 2002

Accepted May 28, 2002.

Corresponding author: C. Burvenich; e-mail: christian.burvenich @rug.ac.be.

\section{INTRODUCTION}

The SCC of milk is generally considered to be an important parameter for mastitis detection because inflammation of the mammary gland results in an influx of somatic cells, predominantly polymorphonuclear neutrophils (PMN), from the blood into the mammary gland (Burvenich et al., 1994). The dairy industry is currently focusing on SCC for reasons of both milk quality and udder health. However, little research has been performed on the immunological significance of the resident cells in milk with respect to resistance against IMI. Although the important role of blood PMN in the pathogenesis of mastitis is well described, the contribution of resident milk cells to the intramammary defense mechanisms is not well characterized. In healthy cows, the number, differential count, and function of leukocytes within the mammary gland could contribute to the defense against invading pathogens. Both naturally occurring (Vandeputte-Van Messom et al., 1993; Shuster et al., 1996) as well as artificially induced (Nickerson et al., 1990) increased SCC have been shown to exert a protective effect against the severity of the inflammatory response to IMI. So far, however, little is known about the qualitative role of milk leukocytes in healthy cows with low SCC milk because the differential leukocyte count in low SCC milk samples is difficult.

Several flow cytometric differential leukocyte count methods for bovine milk have been described (Hageltorn and Saad, 1986; Östensson et al., 1988; Redelman et al., 1988; Saad and Östensson, 1990). These methods have predominantly been developed for high SCC milk samples. In addition, little attention has been paid to the standardization of sample preparation procedures. Milk sample processing varies from the use of centrifuged whole milk samples (Redelman et al., 1988) to dilution with a hypotonic buffer (Hageltorn and Saad, 1986; Östensson et al., 1988). Moreover, the temperature of milk sample collection, storage, and processing is not well described. Flow cytometric identification of bovine milk cells based on forward and side scatter is difficult because phagocytosis of milk components may alter both size and intracellular granularity, and cellu- 
lar debris may interfere with the scatter pattern of normal cells. Therefore, most flow cytometric differential milk leukocyte count techniques are based on fluorescent labeling with monoclonal antibodies against CD molecules or DNA labeling (Darzynkiewicz et al., 1992; Hageltorn and Saad, 1986; Kelly et al., 2000; Pillai et al., 2001). The cells in milk are end-stage cells that have been activated by diapedesis and phagocytosis of milk fat and protein. From preliminary results it was found that they are particularly sensitive to permeabilizing agents, causing drastic alterations of the forward and side scatter pattern. The purpose of our study was to develop a differential leukocyte count method with minimal effects on milk cell morphology, in order to approach the original cellular composition of milk as close as possible. Therefore, alteration of cellular morphology was avoided by using a live cell permeable DNA labeling dye and optimizing the processing and labeling conditions. The study was designed to develop a standard method for differential leukocyte count of low SCC milk.

\section{MATERIALS AND METHODS}

\section{Animals and Milk Sampling}

Healthy Holstein cows from the Ghent University dairy farm (Biocentre Agri-Vet, Melle, Belgium) were selected on the basis of three consecutive bacteriologically negative foremilk samples and SCC below $2 \times 10^{5}$ / $\mathrm{ml}$ milk per individual quarter. For development of the method, cows ( $\mathrm{n}=6)$ in midlactation (150 to $210 \mathrm{~d}$ after calving) were used. For application of the method, cows $(\mathrm{n}=21)$ in three different stages of lactation were used: early lactation ( $22 \pm 4 \mathrm{~d}$ after calving), midlactation (185 $\pm 6 \mathrm{~d}$ after calving) and late lactation $(245 \pm 12 \mathrm{~d}$ after calving). The parity of the cows ranged between 1 and 6 . The cows were milked twice daily. The differential leukocyte count milk samples were foremilk samples, aseptically collected before the morning milking at $0800 \mathrm{~h}$.

\section{SYTO 13 Labeling}

A stock of SYTO 13 (5 mM, Molecular Probes, Eugene, OR) in DMSO was stored at $-18^{\circ} \mathrm{C}$ and diluted 1:40 with RPMI 1640 (Gibco Life Technologies, Gaithersburg, MD) immediately before labeling, according to the manufacturer's prescriptions. This corresponds with a final concentration of $200 \mathrm{n} M$ in the samples. Two other dilutions (1:200 and 1:400; 40 and $20 \mathrm{nM}$ final concentrations, respectively) were also evaluated with low SCC milk samples from five cows, but 1:40 was used for the standard procedure. RPMI $(490 \mu \mathrm{l})$ was added to the cell pellets $\left(1 \times 10^{5}\right.$ to $4 \times 10^{6}$ cells/ $\mathrm{ml}$ ), followed by $10 \mu \mathrm{l}$ of diluted SYTO 13 solution. This was incubated during $0,5,10,20$, and $30 \mathrm{~min}$. A 10-min incubation period was necessary for optimal labeling of all cells (see Results) and was further used for the standard differential leukocyte count procedure.

\section{Flow Cytometry and Cell Sorting}

A flow cytometer (FACScan, Becton Dickinson Immunocytometry Systems, FL) equipped with an argon ion laser was used for measurement of differential leukocyte count. The excitation wavelength of the laser was $488 \mathrm{~nm}$. The forward scatter (FS) signal was amplified with a factor 1.98, whereas side scatter (SSC) and fluorescence signals were not amplified. The voltage applied on the SSC detector was $381 \mathrm{~V}$. The FS and SSC were measured on a linear scale. Four hundred and thirty volts was applied on the photomultipliers for both green and red fluorescence. Green fluorescence was measured with a 530-nm band-pass filter and registered on a log scale, whereas red fluorescence emission was measured with a $650-\mathrm{nm}$ long-pass filter and also registered on a log scale. The data were analyzed using CellQuest (Becton Dickinson) software. Flow cytometric differential leukocyte count of milk after SYTO 13 staining was quantified using the SSC-green fluorescence dot plot. Flow cytometric cell sorting of SYTO 13labeled milk cells was performed using a FACSVantage cell sorter (Becton Dickinson).

\section{Confocal Laser Scanning Microscopy}

A lambda (wavelength) scan was performed on cytospin smears of SYTO 13 labeled milk cells using an inverted confocal laser scanning microscope (DMIRBE HCB fluoro microscope with a TCS SP2 confocal system; Leica Microsystems, Wetzlar, Germany). Four different regions of interest were defined around four different cell types based on size and shape. The fluorescence emission intensity at wavelengths between 498 and 644 $\mathrm{nm}$ was registered for these regions of interest.

\section{Milk Sample Preparation}

All milk samples were gently mixed before dilution and further processing. For the flow cytometric cell sorting procedure, cells were isolated from milk according to Hoeben et al. (1997) and finally resuspended to a concentration of $5 \times 10^{6} / \mathrm{ml}$ after counting with an electronic particle counter (Coulter counter Z2, Coulter Corporation, Miami, FL). For the differential leukocyte count procedure developed in this study, $1.5-\mathrm{ml}$ milk samples were layered on $3.5 \mathrm{ml}$ of PBS into $12-\times 75$ $\mathrm{mm}$ polystyrene flow cytometry tubes (Vel, Leuven, Bel- 
gium) and centrifuged during $10 \mathrm{~min}$ at $180 \times \mathrm{g}$. The fat was removed, the supernatant was discarded, and the tubes were kept upside down until they were carefully cleaned with a cotton swab to remove all fat adhering to the test tube wall. The pellet was then resuspended with $490 \mu \mathrm{l}$ of RPMI for flow cytometric differential leukocyte count or with $1 \mathrm{ml}$ of tryptic soy broth (TSB, Sigma Chemicals, St. Louis, MO) for preparation of microscope slides.

Different dilution buffers were tested with low SCC milk samples from six cows: PBS, RPMI 1640 supplemented with $1 \%$ bovine serum albumin (Sigma) and $0.2 \%$ sodium azide (Sigma) and PBS supplemented with $0.1 \%$ paraformaldehyde (Sigma).

The following dilutions of milk samples were evaluated: $0.5,1.0,1.5$, and $2.0 \mathrm{ml}$ of milk $+4.5,4.0,3.5$, and $3 \mathrm{ml}$ of PBS, respectively, using low SCC milk samples from six cows. To evaluate the effect of temperature on the differential leukocyte count of milk, low SCC milk samples from six cows were maintained at 4,20 , and $37^{\circ} \mathrm{C}$ from immediately after collection, over transportation and processing until flow cytometric analysis. The optimal dilution (1.5 ml of milk with $3.5 \mathrm{ml}$ of PBS) and transportation and processing temperature $\left(20^{\circ} \mathrm{C}\right)$ (see Results) were further used for validation of the standard differential leukocyte count procedure.

\section{Effect of Sample Storage on Differential Leukocyte Count}

The effect of sample storage time was evaluated by comparing the differential leukocyte count of fresh milk samples with samples stored during 24 and $48 \mathrm{~h}$ at $7{ }^{\circ} \mathrm{C}$.

\section{Variability of Differential Leukocyte Count Method}

The variability of the flow cytometric measurement of differential leukocyte count was tested by performing six repeated measurements on one sample. Variability of the complete differential cell count method was evaluated by performing five repetitions of the identification procedure for low SCC milk samples from six different cows. The significance of the difference of identification between the milk samples was evaluated for $2,3,4$, and 5 repeated differential cell counts. The variability of the method was also evaluated at 500, 1000, 2000, and 3000 analyzed cells, with six repeated measurements for each number of cells analyzed in a single sample. In the standard procedure, 3000 cells per sample were analyzed.

\section{Preparation of Microscope Slides and Comparison Between Flow Cytometric and Microscopic Differential Leukocyte Count}

A described procedure for making microscope slides was used (Dulin et al., 1982). Slides were prepared in a cytocentrifuge (Shandon, UK) using $200-\mu \mathrm{l}$ cell suspension with a concentration between 1 and $5 \times 10^{5}$ cells $/ \mathrm{ml}$. The suspensions were centrifuged during 10 $\min$ at $113 \times g$. The smears were stained with MayGruenwald's eosin-methylene blue (Merck Diagnostica, Darmstadt, Germany). At least 200 cells were identified per sample, at a magnification of $\times 1000$. Polymorphonuclear neutrophils (PMN) were identified based on their multi-lobed dark purple stained nucleus and lightly blue stained cytoplasm. PMN were characterized for apoptosis based on the morphologic features of pycnotic nuclei. Mature macrophages were large, with a light purple stained round nucleus and a vacuolated cytoplasm. Milk lymphocytes had the same appearance as their counterparts in the blood. Epithelial cells were large, mostly without nucleus, irregularly shaped, and homogeneously light blue stained. For comparison of the flow cytometric differential leukocyte count method with microscopy, low SCC milk samples from 21 cows in different stages of lactation were prepared in duplicate using the sample preparation method described above. One sample was used for flow cytometry and from the other one, slides were performed in duplicate. Correlation between the $\% \mathrm{LM}, \mathrm{PMN}$, and mature $\mathrm{M} \Phi$ obtained with the two methods was calculated.

\section{Statistical Analysis}

Statistical analysis of the data was performed using statistical software (Statistix 4.0, Tallahassee, FL and SPSS 11, SPSS Inc., Chicago, IL). The effects of sample dilution, temperature, and storage time at $7^{\circ} \mathrm{C}$ were evaluated using analysis of variance. For evaluation of the method variability, the results were subjected to a Wilk Shapiro rankit plot to examine the normality of the distribution of repeated differential cell count analyses. The significance of the difference between the milk samples was evaluated using analysis of variance with cow and repetition as independent variables. If analysis of variance showed significant differences, post-hoc comparisons between averages for different independent parameters were performed using least significant differences.

\section{RESULTS}

\section{Flow Cytometry and Cell Sorting}

Both red and green fluorescence emissions of bovine milk cells were observed following SYTO 13 labeling. Because the best resolution between the populations was obtained with green fluorescence (FL1) and SSC, these parameters were used for the differential leukocyte count procedure. Red fluorescence was reduced at lower SYTO 13 concentrations, but this also resulted 
A

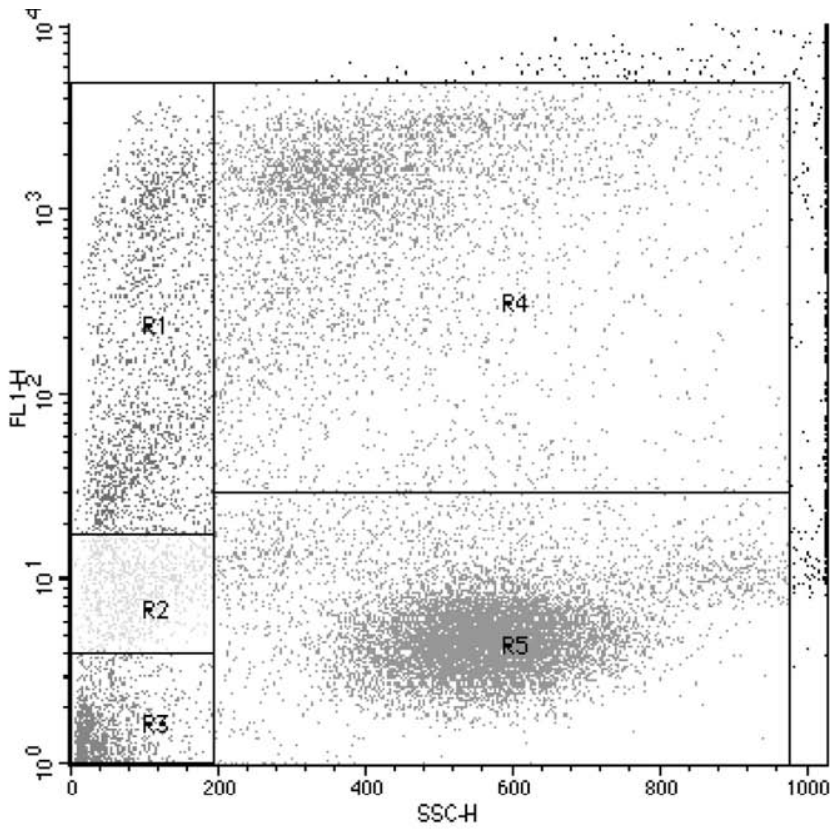

B

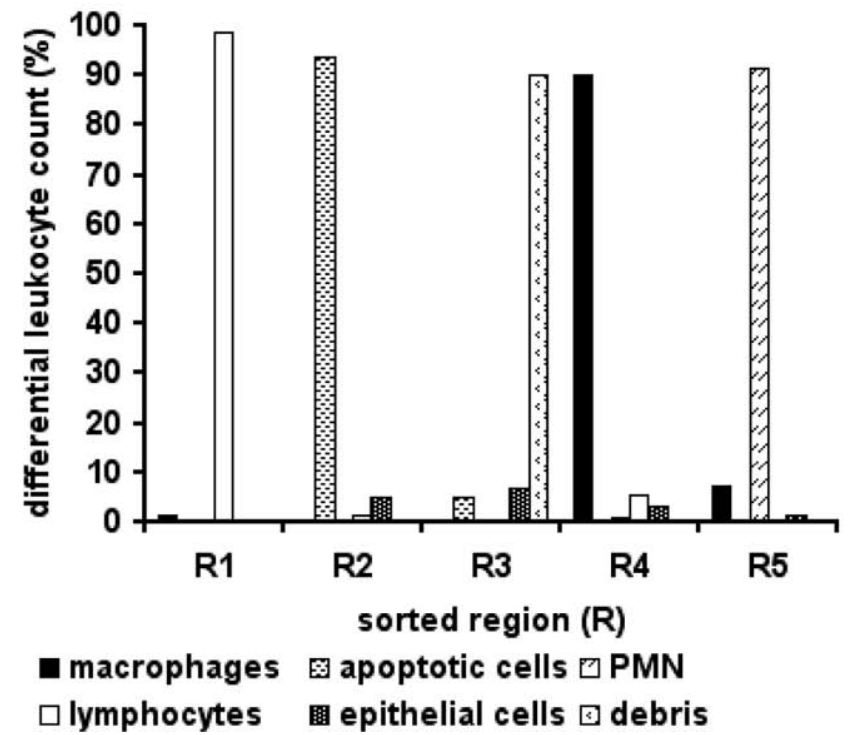

Figure 1. Flow cytometric analysis (A) of SYTO 13-labeled bovine milk cells: green fluorescence (FL-1)—side scatter (SSC) dot plot of isolated milk cells used for flow cytometric cell sorting and subsequent microscopic identification (B). R1: lymphocytes; R2: apoptotic cells; R3: debris; R4: macrophages; R5: polymorphonuclear neutrophil (PMN).

in decreased resolution in the green fluorescence (results not shown). In the FL1-SSC dot plot of isolated cells, five different leukocyte populations were identified (Figure 1). Following flow cytometric cell sorting of SYTO 13 labeled milk cells using the FL1-SSC dot plot (Figure 1), the different cell populations were identified as: 1) $\mathrm{SSC}_{\text {low }}-\mathrm{FL} 1^{\text {high }}$ : high FL1 LM (R1); 2) $\mathrm{SSC}_{\text {low }^{-}}$ FL1 intermediate: intermediate FL1 LM (R1); 3)

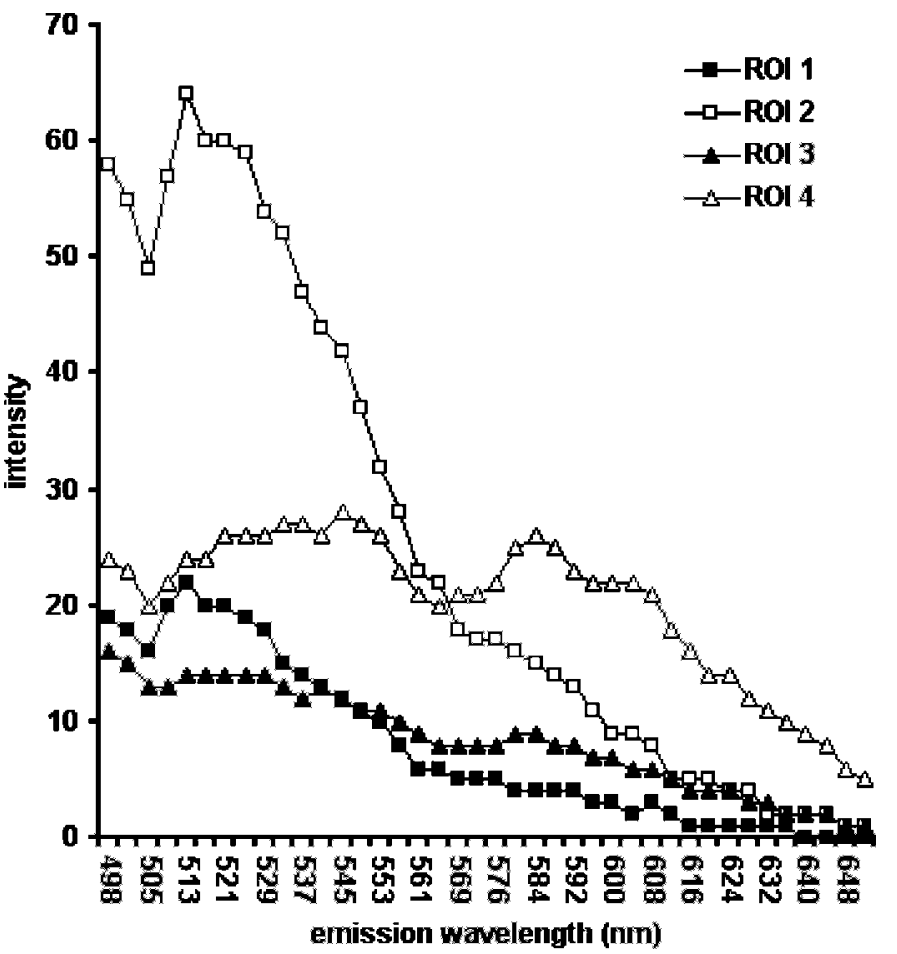

Figure 2. Microscopic identification of SYTO 13-labeled bovine milk cells in different regions following flow cytometric cell sorting. Regions correspond with the regions in Figure 1. R1: lymphocytes; R2: apoptotic cells; R3: debris; R4: macrophages; R5: polymorphonuclear neutrophil (PMN).

$\mathrm{SCC}_{\text {low }}-\mathrm{FL} 1_{\text {low }}$ : cells with apoptotic features (R2); 4) $\mathrm{SSC}^{\text {high }}-\mathrm{FL} 11^{\text {high }}$ : mature $\mathrm{M} \Phi(\mathrm{R} 4)$ and 5$) \mathrm{SSC}^{\text {high }}$-FL1 intermediate: PMN (R5) (Figure 2). Uptake of SYTO 13 did not occur immediately and differed between the cell types (results not shown). Saturation of the fluorescence intensity was obtained in most cell types after $10 \mathrm{~min}$ of incubation and remained nearly constant during $20 \mathrm{~min}$. The highest green fluorescence intensity was observed in mature $\mathrm{M} \Phi$ and viable PMN. Lower fluorescence intensity values were found in cells with apoptotic features, $\mathrm{FL} 1_{\text {low }} \mathrm{LM}$ and debris. For the standard procedure, a 10-min incubation time of cells with SYTO 13 was used.

\section{Confocal Laser Scanning Microscopy}

Using a lambda scan of SYTO 13-labeled milk cells with confocal laser scanning microscopy, a different morphology could be associated with different fluorescence emission characteristics (Figure 3A and B). The cells in region of interest 1 had an intermediate size, were round-shaped with a round nucleus, and had a maximal fluorescence emission at $514 \mathrm{~nm}$. This is consistent with the characteristics of LM. The cells in re- 


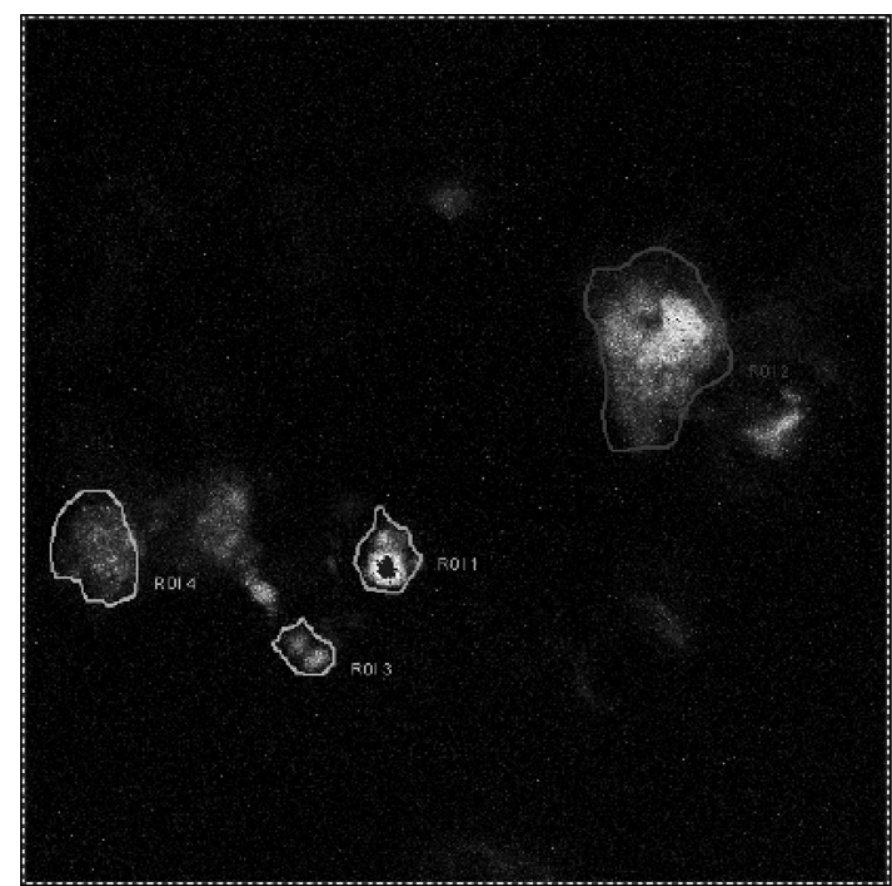

Figure 3. Confocal laser scanning microscopic analysis of fluorescence emission of different SYTO 13-labeled bovine milk cells using a wavelength scan. A) identification of different regions of interest (ROI); B) fluorescence emission characteristics of the different regions of interest identified in A). ROI1: LM (high FL1); ROI2: M $\Phi$; ROI3: PMN; ROI4: LM (high FL1).

gion of interest 2 were large, irregularly shaped, and also had a maximal fluorescence emission at $514 \mathrm{~nm}$, but their fluorescence intensity was much higher than any of the other cell types. These cells conform to the characteristics of mature $\mathrm{M} \Phi$. The cells in region of interest 3 had a multi-lobed nucleus and a maximal but low fluorescence intensity at $498 \mathrm{~nm}$, which are typical features of PMN. Finally, the cells in region of interest 4 had similar fluorescence characteristics as the cells in region of interest 3 , but the fluorescence intensity was higher, especially in the higher emission wavelength region. These cells conform to the characteristics of high FL1 LM.

\section{Milk Sample Preparation and Effect of Storage}

Optimal conditions for milk sample preparation were the following: 1) milk sample dilution with PBS or RPMI-BSA; 2) 30\% (vol/vol) dilution (i.e., $1.5 \mathrm{ml}$ of milk $+3.5 \mathrm{ml}$ of PBS); 3) a sample collection, transportation, and processing temperature of $20^{\circ} \mathrm{C}$. Both the SCC and the differential leukocyte count remained constant throughout a 48 -h storage period at $7^{\circ} \mathrm{C}$.

\section{Variability of the Differential Leukocyte Count Method}

The coefficient of variation for repeated measurements in identical cell suspensions was $1.5 \%$ for LM, $1.4 \%$ for mature $\mathrm{M} \Phi, 0.7 \%$ for $\mathrm{PMN}$, and $0.8 \%$ for cells with apoptotic features. The average coefficients of variation for the complete differential leukocyte count method including sample dilution, resuspension and SYTO 13 labeling of milk samples from six cows were $2.5 \%$ for $\mathrm{LM}, 15.8 \%$ for mature $\mathrm{M} \Phi, 11.8 \%$ for $\mathrm{PMN}$, and $10.7 \%$ for cells with apoptotic features. According to the Wilk-Shapiro rankit plot against the ordered data, which resulted in a straight line, the samples conformed to a normal distribution. Significant differences between the samples were obtained at $P<0.05$ for duplicate differential leukocyte count assays and at $P<0.01$ for 3 or more repeated assays. The highest variability between repeated measurements was observed with 500 analyzed cells. The variability further decreased from 1000 over 2000 to 3000 cells (results not shown). The average percentage of cells in the different regions was not dependent on the number of analyzed cells.

\section{Correlation Between Flow Cytometric and Microscopic Differential Leukocyte Count}

For the LM population, a coefficient of correlation of $0.81(P<0.05)$ and for the PMN population, a coefficient of correlation of $0.90(P<0.01)$ was obtained between flow cytometric and microscopic differential leukocyte count. The coefficient of correlation for the mature $\mathrm{M} \Phi$ count was 0.71 (not significant) between the two methods. For LM, flow cytometric results were systematically higher and for PMN and mature $\mathrm{M} \Phi$, flow cytometric results were systematically lower than microscopic results.

\section{Differential Milk Leukocyte Count in Different Stages of Lactation}

In early lactation, the percentage of LM was higher and the percentage of mature $\mathrm{M} \Phi$ and $\mathrm{PMN}$ were lower than in the other stages of lactation $(P<0.01)$ (Figure 4). Percentages of mature $\mathrm{M} \Phi$ and $\mathrm{PMN}$ in early lactation were only about half of the values found in mid and late lactation. The percentage of cells with apoptotic features was about twice as high in early lactation as in mid and late lactation. Due to the high variability of the percentage of cells with apoptotic features among early lactation cows (a coefficient of variation of $74 \%$ was found); however, this difference was not significant. The differential milk leukocyte count of cows in mid and late lactation was similar. 


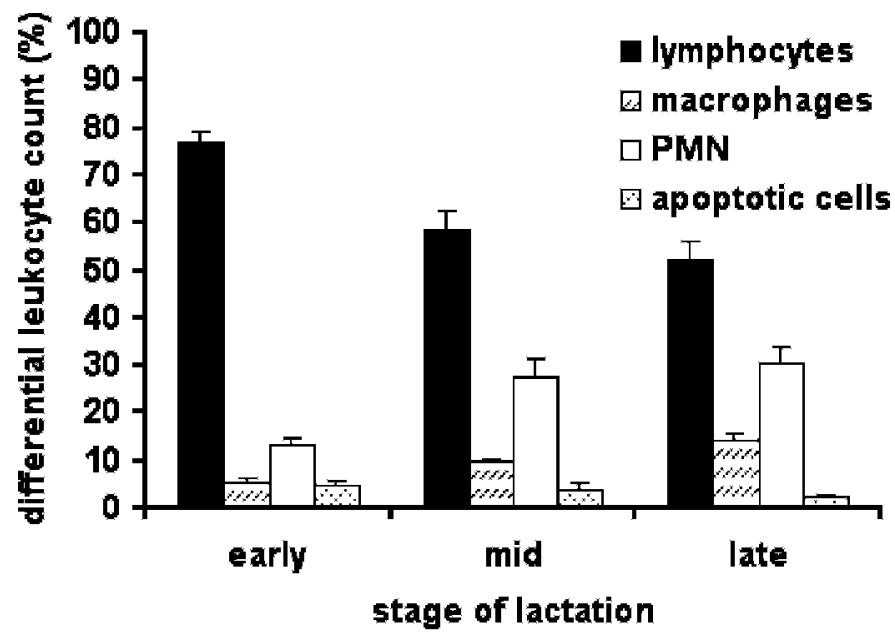

Figure 4. Bar graph of differential milk leukocyte counts for healthy cows $(\mathrm{n}=21)$ with low SCC milk $(\mathrm{SCC}<200,000$ cells $/ \mathrm{ml})$ in early lactation ( $22 \pm 4 \mathrm{~d}$ after calving), midlactation (185 $\pm 6 \mathrm{~d}$ after calving) and late lactation ( $245 \pm 12 \mathrm{~d}$ after calving).

\section{DISCUSSION}

A simple, accurate, and reproducible flow cytometric differential leukocyte count method for low SCC milk from healthy cows was developed in this study. The method is complementary to flow cytometric differential leukocyte count methods for high SCC milk (Pillai et al., 2001; Redelman et al., 1988). The small amount of cells in milk from healthy cows $\left(<10^{5}\right.$ cells $/ \mathrm{ml}$; Laevens et al., 1997), makes the identification of leukocytes more difficult than in high SCC milk $\left(10^{9}\right.$ cells/ ml during coliform mastitis; Dosogne et al., 1997). A maximal amount of identifiable cells in low SCC milk was obtained with 1) a $30 \%$ (vol/vol) dilution of milk samples (which corresponds with large-scale isolations; Hoeben et al., 1997); 2) centrifugation and removal of the fat layer; 3) resuspension of the pellet with RPMI 1640 ; 4) a sample collection, storage and processing temperature of $20^{\circ} \mathrm{C}$. Although the initial SCC of the milk samples was low, a sufficient number of cells was obtained from $1.5-\mathrm{ml}$ samples. Thus, our method is applicable for small volumes of low SCC milk samples. Another advantage of the method described here is that milk samples can be stored for $2 \mathrm{~d}$ at $7^{\circ} \mathrm{C}$ without any effect on the differential leukocyte count. The method was also shown to be reproducible, even at a very low number of cells analyzed: variability was not significantly different between $1000 ; 2000$ or 3000 analyzed cells and the average values for differential milk leukocyte count were not dependent on the number of analyzed cells.

Four populations with different fluorescence emission characteristics were obtained upon SYTO 13 stain- ing of milk leukocytes. The high fluorescence of mature $\mathrm{M} \Phi$ is consistent with previous results obtained with acridine orange labeling (Hageltorn and Saad, 1986) and could be explained by a higher degree of mitochondrial RNA staining. Indeed, green fluorescence obtained with the SYTO dyes is not only governed by stoichiometric DNA binding, but also by cytoplasmic mitochondrial labeling (Poot et al., 1997). The emission wavelength maximum of SYTO 13-labeled RNA (514 $\mathrm{nm}$ ) is similar to DNA (509 nm) (Molecular probes, SYTO green fluorescent nucleic acid stains product information sheet). Mitochondrial labeling could also explain the high green fluorescence of some LM and is indicative of a high metabolic rate. PMN and LM had similar fluorescence characteristics but could be distinguished on the basis of cytoplasmic granularity, which was typically higher for PMN than for LM.

In addition to normal viable leukocytes, a significant proportion of cells with apoptotic features could be detected. This is consistent with the "degenerating cells" found in milk using carboxydimethylfluorescein diacetate labeling (Redelman et al., 1988). These cells were characterized as apoptotic based on their lower green fluorescence and their smaller size in the FS-SSC dot plot in comparison with living cells. Features of apoptosis were confirmed using morphological analysis after cell sorting. In general, a decreased stainability with DNA-specific fluorochromes and a decreased FS have been described as methods to identify apoptotic cells (Darzynkiewicz et al., 1992). With the SYTO dyes, including SYTO 13, a decreased green fluorescence has been found to characterize apoptotic human lymphoid B cells in comparison with living cells (Poot et al., 1997). Together, both from literature data and from our experimental results, it can be suggested that bovine milk cells with decreased green fluorescence emission upon SYTO 13 labeling were indeed apoptotic.

The percentage of PMN, mature $\mathrm{M} \Phi$, and LM during different stages of lactation found using the new technique correspond well with other flow cytometric differential leukocyte count results in literature (Östensson et al., 1988; Leitner et al., 2000; Pillai et al., 2001). Differential milk leukocyte counts obtained with flow cytometry may, however, differ from microscopic results: for example, higher PMN counts were found using flow cytometry than with microscopy (Miller et al., 1993). These differences could be explained by disruption of aged and apoptotic PMN during preparation of slides, resulting in lower microscopic PMN counts. Divergent differential milk leukocyte count results may also be explained by different definitions of milk cell types. This is particularly the case for the monocytemacrophage population. With our method, monocytes were distinguished separately from mature $\mathrm{M} \Phi$. This 
may explain the lower percentage of mature $\mathrm{M} \Phi$ with our method than what is described in literature (Concha et al., 1988). However, if LM and $\mathrm{M} \Phi$ are counted together, as performed by Pillai et al. (2001), our results correspond well with their results obtained from uninfected quarters.

Using the developed differential leukocyte count method, we have found a 2 times increased percentage of apoptotic milk cells in early lactation in comparison with midlactation. This is consistent with previous findings using Annexin V-FITC staining and light microscopy (Van Oostveldt et al., 2001). Whereas the impact of this finding for susceptibility to mastitis remains to be investigated, the presence of a high number of apoptotic cells may significantly compromise the capacity of resident milk cells to mount an adequate immune response upon infection. Indeed, not only have apoptotic PMN a decreased bactericidal capacity (Van Oostveldt et al., 2002), but also can they compete with pathogens for phagocytosis by $\mathrm{M} \Phi$.

In conclusion, a simple and rapid standard flow cytometric procedure was developed to perform differential leukocyte counts in low SCC milk from healthy cows.

\section{ACKNOWLEDGMENTS}

This study was supported by the Belgian Ministry of Small Enterprises and Agriculture (grant S/5871) and by the Belgian Fund for Scientific Research (FWO, grant 31504200 ). The authors thank L. De Bruyne, E. Vander Elstraeten and A. Van Driessche for technical assistance. The expert assistance of M. De Smedt and Prof. Dr. Plum (Ghent University Hospital) with flow cytometric cell sorting is greatly appreciated.

\section{REFERENCES}

Burvenich, C., M. J. Paape, A. W. Hill, A. J. Guidry, R. H. Miller, R. Heyneman, W. D. J. Kremer, and A. Brand. 1994. Role of the neutrophil leukocyte in the local and systemic reactions during experimentally induced $E$. coli mastitis in cows immediately after calving. Vet. Q. 16:45-49.

Darzynkiewicz, Z., S. Bruno, G. Del Bino, W. Gorczyca, M. A. Hotz, P. Lassota, and F. Traganos. 1992. Features of apoptotic cells measured by flow cytometry. Cytometry 13:795-808.

Dosogne, H., C. Burvenich, T. van Werven, E. Roets, E. N. Noordhuizen-Stassen, and B. Goddeeris. 1997. Increased surface expression of CD11b receptors on polymorphonuclear leukocytes is not sufficient to sustain phagocytosis during Escherichia coli mastitis in early postpartum dairy cows. Vet. Immunol. Immunopathol. 60:47-59.
Dulin, A. M., M. J. Paape, and B. T. Weinland. 1982. Cytospin centrifuge in differential counts of milk somatic cells. J. Dairy Sci. 65:1247-1251.

Hageltorn, M., and M. A. Saad. 1986. Flow cytofluorometric characterization of bovine blood and milk leukocytes. Am. J. Vet. Res. 47:2012-2016.

Hoeben, D., C. Burvenich, and R. Heyneman. 1997. Influence of antimicrobial agents on bactericidal activity of bovine milk polymorphonuclear leukocytes. Vet. Immunol. Immunopathol. 56:271282.

Kelly, A. L., D. Tiernan, C. O'Sullivan, and P. Joyce. 2000. Correlation between bovine milk somatic cell count and polymorphonuclear leukocyte level for samples of bulk milk and milk from individual cows. J. Dairy Sci. 83:300-304.

Laevens, H., H. Deluyker, Y. H. Schukken, L. De Meulemeester, R. Vandermeersch, E. De Muelenaere, and A. de Kruif. 1997. Influence of parity and stage of lactation on the somatic cell count in bacteriologically negative dairy cows. J. Dairy Sci. 80:32193226 .

Leitner, G., E. Shoshani, O. Krifucks, M. Chaffer, and A. Saran. 2000. Milk leukocyte population patterns in bovine udder infection of different aetiology. J. Vet. Med. B 47:581-589.

Miller, R. H., M. J. Paape, R. Filep, and S. Link. 1993. Flow cytometric analysis of neutrophils in cows' milk. Am. J. Vet. Res. 54:1975-1979.

Nickerson, S. C., R. L. Boddie, W. E. Owens, and J. L. Watts. 1990. Effects of novel intramammary device models on incidence of mastitis after experimental challenge. J. Dairy Sci. 73:2774-2784.

Östensson, K., M. Hageltorn, and G. Astrom. 1988. Differential cell counting in fraction-collected milk from dairy cows. Acta Vet. Scand. 29:493-500.

Pillai, S. R., E. Kunze, L. M. Sordillo, and B. M. Jayarao. 2001. Application of differential inflammatory cell count as a tool to monitor udder health. J. Dairy Sci. 84:1413-1420.

Poot, M., L. L. Gibson, and V. Singer. 1997. Detection of apoptosis in live cells by Mitotracker Red CMXRos and SYTO dye flow cytometry. Cytometry 27:358-364.

Redelman, D., S. Butler, J. Robison, and D. Garner. 1988. Identification of inflammatory cells in bovine milk by flow cytometry. Cytometry 9:463-468.

Saad, A. M., and K. Östensson. 1990. Flow cytofluorometric studies on the alteration of leukocyte populations in blood and milk during endotoxin-induced mastitis in cows. Am. J. Vet. Res. 51:16031607.

Shuster, D. E., E. K. Lee, and M. E. Kehrli. 1996. Bacterial growth, inflammatory cytokine production and neutrophil recruitment during coliform mastitis in cows within ten days after calving, compared with cows at midlactation. Am. J. Vet. Res. 57:15691575.

Vandeputte-Van Messom, G., C. Burvenich, E. Roets, A.-M. MassartLeën, R. Heyneman, W. D. J. Kremer, and A. Brand. 1993. Classification of newly calved cows into moderate and severe responders to experimentally induced Escherichia coli mastitis. J. Dairy Res. 60:19-29.

Van Oostveldt, K., M. J. Paape, H. Dosogne, and C. Burvenich. 2002. Effect of apoptosis on phagocytosis, respiratory burst and CD18 adhesion receptor expression of bovine neutrophils. Domest. Anim. Endocrinol. 22:37-50.

Van Oostveldt, K., F. Vangroenweghe, H. Dosogne, and C. Burvenich. 2001. Apoptosis and necrosis of blood and milk polymorphonuclear leukocytes in early and midlactating cows. Vet. Res. $32: 617-622$. 